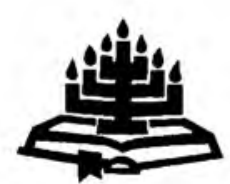

\title{
Name, name, name ... 'n blik op die name van dle Onafhanklike Swart Kerke
}

\author{
J.J. (Dons) Kritzinger \\ Departement Godsdiens- en Sendingwetenskap \\ Universiteit van Pretoria \\ PRETORIA \\ E-posadres: jikrit@ccnet.up.ac.za
}

\begin{abstract}
:
Names, names, names ... a perspective on the names of the Alrican Independent Churches

In the South African population censuses of the past the thousands of African Independent Churches were all classified and tabled together in one category. Since 1980 only one, the Zion Christian Church, has been identified separately. Previous statistics did not make it possible to know which of these churches were the larger ones, where they were based, and which groups were growing as these statistics were very general. This article gives the reasoning behind the proposal made to the Central Statistical Services to enumerate some of these churches separately, and to classify the more or less 4500 churches into a number of categories on the basis of their stated names.
\end{abstract}

\section{Inleiding}

Hierdie artikel handel basies oor die interessante verskeidenheid name wat ons by die Onafhanklike Swart Kerke aantref, en nie soseer oor hul "leer" en "lewe" nie.

1 Van prof. Koos van Rooy se vroegste navorsing in Venda het te doen gehad met die verskynsel van sinkretisme in die Onafhanklike Swart Kerke. Alhoewel hy later nie meer eksplisiet hieroor gepubliseer het nie, het baie van sy werk implisiet met hierdie saak bly verband hou. Hy het stceds besig gebly met die uitdagings vir die kerk in Afrika, en meer in besonder die opdrag om 'n Bybelse lewens- en wêreldbeskouing in die kerk in Afrika te laat gestalte kry. Hierdie navorsing oor die Onafhanklike Swart Kerke word dus aan kollega Koos van Rooy opgedra Anders as Van Rooy hou ek my minder besig met hierdie Kerke se "leer" en "lewe" as met hulle struktuur en hulle omvang. 
Gedurende die tagtigerjare het ek 'n intensiewe verwerking gedoen van die vorige, maar in besonder die 1980-bevolkingsensus ${ }^{2}$. Een van die duidelikste en belangwekkendste bevindinge van hierdie navorsing was dat die Onafhanklike Swart Kerke (OSKs) nie alleen teen 'n groot tempo aan die groei was nie, maar dat dit ook alreeds in 1980 die grootste enkele godsdienstige groepering in SuidAfrika was. Vereenvoudigd was die godsdienstige prentjie van die 1980 -sensus soos volg:

Tabel 1: Die godsdienstige samestelling van die bevolking van Suid-Afrika in 1980

\begin{tabular}{|l|l|l|l|l|l|}
\hline Groepering & Swartes & Blankes & Kleurlinge & Asiërs & TOTAAL \\
\hline Tradisionele Kerke & 41,8 & 82,3 & 76,8 & 8,2 & 51,8 \\
\hline $\begin{array}{l}\text { Onafhankl. Swart } \\
\text { Kerke }\end{array}$ & 30,1 & 0,0 & 3,4 & 0,0 & 20,8 \\
\hline Ander Kerke & 2,3 & 9,5 & 6,8 & 4,3 & 4,1 \\
\hline Subtotaal & $\mathbf{7 4 , 1}$ & $\mathbf{9 1 , 8}$ & $\mathbf{8 7 , 0}$ & $\mathbf{1 2 , 5}$ & $\mathbf{7 6 , 7}$ \\
\hline Hindoes & 0,0 & 0,0 & 0,0 & 64,1 & 2,1 \\
\hline Moslems & 0,1 & 0,0 & 6,7 & 20,3 & 1,4 \\
\hline Ander & 0,6 & 3,2 & 1,2 & 1,5 & 1,2 \\
\hline Onbekend & $\mathbf{2 5 , 2}$ & $\mathbf{5 , 0}$ & $\mathbf{5 , 1}$ & 1,6 & 18,6 \\
\hline Subtotaal & $\mathbf{2 5 , 9}$ & $\mathbf{8 , 2}$ & $\mathbf{1 3 , 0}$ & $\mathbf{8 7 , 5}$ & $\mathbf{2 3 , 3}$ \\
\hline Groottotaal & $\mathbf{1 0 0 , 0}$ & $\mathbf{1 0 0 , 0}$ & $\mathbf{1 0 0 , 0}$ & $\mathbf{1 0 0 , 0}$ & $\mathbf{1 0 0 , 0}$ \\
\hline
\end{tabular}

Statisties gesproke, was daar in die sensusgegewens ten opsigte van die Onafhanklike Swart Kerke (OSKs) hoofsaaklik twee probleme.

- Die eerste leemte was dat die duisende ${ }^{3}$ OSKs almal saamgegroepeer is en aangedui is as een groep, terwyl (soos die term aandui) dit juis kenmerkend

2 Kyk vir publikasies hieroor Kritzinger, 1986a, 1986b en 1986c.

3 Dit is nie duidelik hoeveel OSKs daar werklik is nie Soms word die getal van agt duisend genoem. Volgens prof. G.C. Oosthuizen, die doyen van studies op hierdie terrein, se opmerkings by die NERMIC simposium in Julie 1997, is daar sedert 1925 van hierdie kerke verwag om by die betrokke departement van die regering te registreer. Aangesien dit vir hierdie groepe belangrik 
van hulle is dat hulle onafhanklik van mekaar bestaan, en meestal baie ernstig is oor hulle afsonderlikheid. Daar is betekenisvolle verskille tussen hierdie Kerke, al sou daar ook gemeenskaplikhede wees. Tog was daar nog geen poging aangewend om hierdie duisternis Kerkies verder te klassifiseer in kleiner groepe nie. Dit is tog 'n ernstige veralgemening om hierdie miljoene mense (in duisende Kerke) eenvoudig saam te groepeer.

- Die ander leemte was dat slegs een kerk, die Zion Christian Church $(\mathrm{ZCC})^{4}$, afsonderlik geklassifiseer en getabelleer is. Die belangrike vraag oor watter van hierdie Onafhanklike Kerke die grootstes was, kon dus nie tot dusver uit die sensustabelle afgelei word nie.

Daar kon ook nie toestemming verkry word om deur middel van die nagaan van 'n steekproef van sensusopgawes groter duidelikheid te kry oor die relatiewe grootte van die verskillende Kerke nie. Die amptelike antwoord was dat die ondememing van vertroulikheid wat aan die publiek gegee is, dit onmoontlik maak dat die vorms na buite beskikbaar gestel kon word. Wat die 1980-gegewens betref, moes dit so aanvaar word. Die volgende (1985) sensus was nie omvattend nie, en het geen vraag oor godsdienstige affiliasie gevra nie. Ongelukkig het die 1991-sensus dieselfde leemtes as dié van 1980 gehad. Maar meer nog: vir die eerste keer is daar nou eksplisiet aan die publiek gestel dat die beantwoording van die vraag oor godsdienstige affiliasie opsioneel is. Geen ander vraag in die vorm was op dieselfde manier as "privaat saak" gehanteer nie. Hierdie inligting was skynbaar nie van openbare belang nie5. Die resultaat was natuurlik voorspelbaar: bykans $30 \%$ van alle respondente het by hierdie vraag verbygegaan

was om erkenning te verkry, was hulle baie nougeset hiermee. Uiteindelik, in 1963, is hierdie vereiste opgehef, maar het die kerke voortgegaan om by wyse van briewe en/of konstitusies hulleself te "registreer". Die kumulatiewe lêers, sê Oosthuizen, bevat dus 'n lys van 7500 name Aan die ander kant word dikwels van 'n getal van 6000 gepraat Die lys waarop ek die analises in die res van hierdie artikel baseer, bevat die 4553 name wat die Sentrale Statistiekdiens uit die sensusvorms saamgestel het.

4 Dit is bekend dat daar twee "takke" van die ZCC is, die resultaat van die skeiding toe twee broers in 1948 om dic leierskap meegeding hct na die dood van hulle vader, Ignatius (Engenas) Lekganyane, die stigter. In 1980 is $750000 \mathrm{ZCC}$ aanhangers in die sensustabelle aangedui Dit is onduidelik of die aanhangers van albei hierdie kerke in hierdie getal ingesluit is, en of selfs ander wat hullesilf "Sioniste" noem, hierby ingesluit word.

5 Dit is terloops 'n baie ernstige saak wat met die owerhede uitgeklaar moet word Dit is een van die dwalings van die modemisme dat godsdiens eenvoudig na die private sfeer verskuif word, die terrein van persoonlike oortuigings, subjektiewe opinie. In die openbare lewe is net sogenaamde "feitelikhede" skynbaar belangrik. 
en geen godsdienstige inligting verskaf nie. Dit het die godsdienstige gegewens van hierdie sensus feitlik nutteloos gemaak ${ }^{6}$.

Ten spyte van ons besware (dalk was die besware nie hoorbaar genoeg oorgedra nie) het die "eerste demokratiese sensus" van September 1996 dieselfde swakheid behou. Weereens was hierdie vraag die enigste in die vraelys waarvan die beantwoording opsioneel was ${ }^{7}$. Hierdie sensus se godsdienstige gegewens was nog nie in Mei 1998 gepubliseer nie, maar die tragedie is dat ons waarskynlik ook deur hierdie sensus in die steek gelaat gaan wees wanneer ons die jongste godsdienstige gegewens benodig.

Daar was egter wel vordering. Die Sentrale Statistiekdiens (SSD) het besluit om meer te wete te kom oor die groot groep kerke wat as "Ander Onafhanklike Swart Kerke" gegroepeer is. 'n Navraag is in hierdie verband gedoen: is daar nie ander van hierdie kerke (afgesien van die ZCC) wat afsonderlik getabelleer kon word nie? Watter is die grootstes van die OSKs? Soos reeds hierbo verduidelik is, is ons nie in die posisie om dit te kan antwoord nie. Ons het hoogstens indrukke.

Op grond van die advies van verskillende kenners is voorgestel dat die volgende kerke by die lys gevoeg sou kon word: die "African Methodist Episcopal Church" (AMEC), die "(I)Bandla LamaNazaretha" (van Shembe), die "International Pentecost Church" (van Modise), die "St Engenas Zion Christian Church" (die ZCC met die duif-embleem), en die "St John's Apostolic Church", benewens die ZCC (met die ster) ${ }^{8}$. Die indruk bestaan dat hierdie aanbeveling aanvaar is.

\section{Die huidige kodelys vir godsdienstige groeperings}

Dalk is dit nodig om op hierdie stadium 'n aanduiding te gee van die kodelys (in Engels) wat deur die verwerkers gebruik word ten einde die tabellering van die

6 Ek dink nie dat enige betekenisvolle afleidings uit die godsdienstige gegewens van die 1991sensus gemaak kan word nie. Ons weet nıks van die mense wat die vraag nie beantwoord het nie. Hulle kon van enige moontlike godsdienstige affiliasie wees. Hierdie punt is beredeneer in Kritzinger (1993a, 1993b en 1994)

7 Die verskansing van persoonlike menseregte wat in die nuwe Suid-Afrika baie belangrik geword het, moet myns insiens nie tot absurditeit gevoer word nie. Waarom geld die reg tot privaatheid in die sensusgegewens net op hierdie een terrein?

8 Terselfdertyd is van die geleentheid gebruik gemaak om ook 'n paar ander voorstelle te maak. Die belangrikste van hierdie voorstelle was om die kategorie "Afrika tradisionele godsdienste" by te voeg. Dit was nog nooit tevore in 'n bevolkingsensus moontlik vir 'n persoon om hom/haarself as 'n Afrika-tradisionalis te identifiseer nie. Dit was tot dusver 'n emstige oorsig 
godsdienstige gegewens moontlik te maak. Die jongste voorstelle word reeds hierin opgeneem. Hier en daar word 'n opmerking bygevoeg.

\section{Kodebeskrywing}

\section{Christian Churches}

01 Dutch Reformed Church family

02 Reformed Churches in SA

03 Nederduitsch Hervormde Kerk

04 Anglican Church

05 Church of England in SA (so stated)

06 International Fellowship of Christian Churches 9

07 United Methodist Church of Southern Africa

08 Presbyterian Churches

09 United Congregational Church of SA

10 Lutheran Churches

11 Roman Catholic Church

12 Apostolic Faith Mission of SA

13 Other Apostolic Churches

14 Baptist Churches of SA

15 Pinkster Protestantse Kerk

16 Afrikaanse Protestantse Kerk

17 Full Gospel Church of God in SA

18 Greek Orthodox Church

19 Church of Christ of Latter Day Saints ${ }^{10}$

20 Pinkster Evangelie Kerk van SA 11

21 Salvation Army United Church

22 Seventh Day Adventist Church

23 New Apostolic Church

9 Dit is te betwyfel of hierdie 'n sinvolle groepering is. Mense sou hulleself sien as lidmate van een van die deelnemende Kerke.

10 Dit is te betwyfel of hierdie onder die Christelike groepe geklassifiseer kan word.

1 Hierdie naam is (aan skrywer) onbekend 
24 Swiss Church ${ }^{12}$

25 Assemblies of God in SA

26 St Engenas Zion Christian Church

27 Zion Christian Church

28 (I)Bandla LamaNazaretha (Shembe)

29 African Methodist Episcopal Church

30 St John's Apostolic Church

31 International Pentecost Church (Modise)

32 Other African Independent Churches

33 Other Christian Churches

Other religions/faiths

34 African Traditional Belief

35 Jewish Faith/Hebrew

36 Buddhism

37 Taoism

38 Confucianism

39 Hindu Faith

40 Muslim Faith

41 Bahai Faith

42 New Age

43 New Religionist ${ }^{13}$

44 Other non-Christian religions

45 No religion or belief (so stated)

46 Refused to report (so stated)

99 Not stated/reported

Die SSD wou egter nog verder gaan: is dit nie moontlik om die res van die sowat 4500 name wat saamgegeroepeer is as "Ander OSKs" tog verder te verdeel in kategorieë nie? Die huidige klassifikasie is te groot en lomp. Hierdie artikel

12 Hierdie Kerk behoort by die Presbiteriane geplaas te word

13 Hierdie is ' $n$ verwarrende benaming 
reflekteer my nadenke oor hierdie versoek, en die uiteindelike voorstelle wat gemaak is.

\section{3. 'n Voorbeeld}

Sodat die leser 'n gevoel kan kry van die soort gegewens waarmee hier gewerk word, volg 'n aantal name uit die lys as 'n voorbeeld. Hierdie is 'n seleksie van kerkname wat met $\mathrm{D}$ begin. (Ek het die $\mathrm{D}$ gekies omdat dit 'n redelike kort lysie is, slegs 71 name.)

D I Five Eight Jerusalem Apostolic Church in Zion

Dam of Betesda in Zion of SA

Damascus Bethesta Apostolic Church in Zion of SA

Damascus Voice of Apostolic Church in Zion of SA

Damaseku Apostolic Church in Zion of SA Ekhutanyeni of SA

Damaseku Holy Bethlehem Apostolic Church in Zion of SA

Damaseku Mission Christian New Salem Church in Zion of SA

Ded Side Fide Gates Apostolic Church in Zion

Defence Ethiopian Church SA

Dependant Church in South Africa

Descendants of The Apostles Church in Christ in RSA

Devotional Spiritualist Apostolic Christian Faith Church of Christ

Diketso Tsabapostola Church in Africa

Dominion New Pentecostal Holiness Church of RSA

Donation Apostolic Church in Zion of SA

Double Blades Glorious Freedom Church of God

By 'n eerste deurgaan van die lys name is dit reeds duidelik dat sommige name verkeerd geskryf is. Maar wie gaan besluit of dit regtig die geval is? Ander (soos "Die Nuwe Protestantse Kerk in Afrika", die "Disciples of Christ" en die "Dobsonville Muslin (sic) Society") is kennelik nie Onafhanklike Swart Kerke nie. Dit was dus hoog tyd dat iemand die lys met 'n fynkam moes deurgaan, dupliserings en foute uitskakel, en dalk tot 'n fyner klassifikasie kom. Dit is egter baie onwaarskynlik dat daar iemand is, of selfs 'n groep navorsers gesamentlik, wat meer as slegs 'n klein persentasie van hierdie kerke ken. 'n Klassifikasie op grond van inhoudelike kennis van hierdie kerke is prakties onmoontlik. 


\section{Klassifikasiebeginsels}

Die poging wat wel aangewend is, het as uitgangspunt geneem dat die name van kerke belangrik is vir hulle aanhangers, en sekerlik vir hulle stigters/leiers. Daar moes dus bepaalde redes wees waarom 'n spesifieke naam gekies is. Dikwels kom die naam op ' $n$ bonatuurlike manier (of in 'n droom) na die stigter of leier van 'n kerk. Ander kere, weer, reflekteer die naam die belangrikste skeidingsbeginsel, of die herkoms. Maar in die naam lê tog iets van die visie en identiteit van die kerk ${ }^{14}$. Daarom moet dit in beginsel moontlik wees om op grond van die name tot een of ander klassifikasie te kom. Dit is presies wat hier probeer word.

'n Paar benaderings of stappe sou gevolg kon word. In die eerste plek is daar die tradisionele klassifikasies van Ethiopies, Apostolies en Sionisties ${ }^{15}$ ). In sommige gevalle sou dit moontlik wees om hulle op grond van die name in hierdie klassifikasie te groepeer, maar in die meeste gevalle is dit nie so voor die hand liggend nie.

'n Tweede benadering sou wees om families te identifiseer. Dit sou 'n boeiende studie wees om deur middel van genealogiese studies by sulke groeperings uit te kom. Ons weet dat sekere kerke 'n belangrike rol gespeel het in die aanvanklike ontstaan van die OSKs. So het die "Ethiopian Church" en die "African Methodist Episcopal Church" die "moeders" geword van vele Ethiopiese tipe kerke; uit die "Christian Catholic Apostolic Church in Zion" het die Sionistiese beweging gevloei; en uit die "Apostoliese Geloof Sending" het talle van die Apostoliese kerke ontwikkel. Maar die dinamiek van die afskeidings en nuwe kerkvormings is so ingewikkeld dat hierdie "families" spoedig nie meer identifiseerbaar is nie.

Miskien sou die voorkoms van sekere sterk woorde in die name 'n klassifikasie moontlik maak. Daarmee sou albei vorige benaderings ook opgevang kan word. Ons kyk dus na woorde soos "Zion", "Apostle/Apostolic", "Holy Spirit", "Jerusalem", "Africa/Ethiopia", ensovoorts.

Dit was dan ook die benadering wat ek in hierdie voorstel volg. Ongelukkig was ook dit nie so maklik nie, want in die oorgrote meerderheid gevalle het sommige van hierdie kragtige elemente saam in die name voorgekom, waarskynlik juis om groter krag aan die naam te verleen. Toe moes onderskei word watter van hierdie terme die belangrikste in die kombinasie figureer. Tot 'n baie groot mate moes in

Dit sou 'n besonder interessante studie wees om meer kwalitatief navorsing te doen oor die corsprong van die name van kerke. Waarom, byvoorbeeld, die laaste naam in bostaande lys "Double Blades Glorious Freedom Church of God"? En die eerste, die "D I Five Eight Jerusalem Apostolic Church in Zion"? En die "Dependant (sic) Church in SA"?

15 Hierdie klassifikasie kan beskou word as die mees gangbare, maar 'n verskeidenheid ander is al voorgestel Sundkler (1961:302) het bv 'n "Messiaanse tipe" ook bygevoeg 
hierdie opsig maar intuitief te werk gegaan word. Die klassifikasies kan onmoontlik waterdig wees, en moet oop bly vir verdere diskussie ${ }^{16}$.

\section{5. 'n Voorgestelde klassifikasie}

Die 97 gedrukte bladsye met die lys van 4553 name is 'n paar keer deurgegaan. $\mathrm{Na}$ die eerste rondte is ' $\mathrm{n}$ voorlopige klassifikasie gedoen. By die tweede lesing is dit toegepas en gekorrigeer. Soos hierbo aangedui, is die voorstel gebaseer op

- die voorkoms van sekere kenmerkende terme in die name,

- 'n beslissing oor watter van die terme die belangrikste posisie in die naam inneem, en

- die (toevallige) kennis van sekere kerke

Dikwels was die keuse heel subjektief. Verskeie van die voorgestelde klassifikasies is waarskynlik nie finaal nie, en die grenslyne onduidelik. Tog meen ek dat hierdie poging, met sy gebreke, reeds veel beter is as die vorige gebrek aan enige klassifikasie, want die kerke wat verkeerd geklassifiseer mag wees, sal statisties gesproke nie veel verskil maak in terme van die totale getalle nie.

Die voorstel kom daarop neer dat die nagenoeg 4500 kerke, wat vroeër in die twee kategoriee 32 ("Other African Independent Churches") en 33 ("Other Christian Churches") geklassifiseer was, nou in 16 nuwe groepe verdeel is, en dat sewe nuwe kerke vir individuele tabellering kwalifiseer. (Na laasgenoemde is reeds hierbo verwys.) Dit begin met die kategoniee "Ander Metodiste", "Ander Presbiteriane", ens., omdat dit opgeval het hoeveel kerke steeds hierdie tradisionele denominasionele beskrywings ook in hulle name gebruik. Hierdie groeperings word ten slotte aangevul met 'n aantal nuwes. In die lys wat nou volg, is hierdie aanvullings donker gedruk. Die lys is ook verander na 'n ietwat logieser volgorde.

\section{Code Description}

\section{Christian Churches}

01 Dutch Reformed Church family

02 Reformed Churches in SA

03 Nederduitsch Hervormde Kerk

16 Dit is die doel van hierdie artikel. Hierdie voorstelle is reeds in Julie 1997 deur spesialiste bespreek by die simposium van NERMIC (die navorsingseenheid oor New Religions and Independent Churches) Ongelukkig is dit nie moontlik om hier al die voorstelle te publiseer ne Ons sal moet volstaan met 'n paat voorbeelde. Dit is juis om 'n diskussie oor die benadenng uit te lok dat hierdie verhaal vertel word. 
04 Afrikaanse Protestantse Kerk

05 Anglican Church

06 Church of England in SA (so stated)

07 United Methodist Church of Southem Africa

08 Other Methodist churches

09 Presbyterian Churches (including the Swiss Church or Mission)

10 Other Presbyterian churches

11 United Congregational Church of SA

12 Other Congregational churches

13 Lutheran Churches

14 Other Lutheran churches

15 Baptist Churches of SA

16 Other Baptist churches

17 Roman Catholic Church

18 Other Catholic churches

19 Apostolic Faith Mission of SA

20 Pinkster Protestantse Kerk

21 Full Gospel Church of God in SA

22 Assemblies of God in SA

\section{Other Assemblies}

24 Salvation Army United Church

25 Other Pentecostal churches (operative words like Immanuel, Latter Rains, Healing, Revival, etc)

26 Christian Centres (also Community Churches, Union Churches, Fellowships, etc.)

27 Church of the Nazarene

28 Other Evangelical churches (operative words like Gospel, Mission, etc.)

29 International Fellowship of Christian Churches

30 Other Charismatic churches

31 Seventh Day Adventist Church

32 Other (Seventh Day) Adventist churches (operative word is Sabbath, Seventh, etc) 
33 Greek Orthodox Church

34 Other Orthodox churches

35 New Apostolic Church

36 Other Apostolic Chiurches

37 St Engenas Zion Christian Church

38 Zion Christian Church

39 (I)Banda LamaNazaretha (Shembe)

40 Other Zionist churches

41 African Methodist Episcopal Church

42 Ethnic churches (Bakgatla, Zulu, etc stated)

43 Other Ethiopian type churches (predominance of Bantu, Africa, Ethiopia, Native, etc.)

44 St John's Apostolic Church

45 International Pentecost Church (Modise)

46 Other African Independent Churches

47 Christian Scientist

48 Other Christian churches (where there is still uncertainty)

49 Church of Christ of Latter Day Saints

Hierdie voorstel moes daarna getoets word. Dit word geillustreer aan die hand van die eerste name op die lys, beginnende met A. Dit het gou duidelik geword dat die meeste name nou in groepe teregkom soos "Other Zionist", of "Other Apostolic", maar dat baie tog ook beland in die groeperinge "Other Ethiopian", "Other Pentecostal", "Evangelical" en "Charismatic". Reeds uit hierdie voorbeelde sal dit ook duidelik word hoe subjektief en moeilik baie van hierdie besluite is.

08 Other Methodist churches

African Bantu Methodist Church

African Christian Methodist Church of SA

10 Other Presbyterian churches

African Free Presbyterian Church of SA

African Presbyterian Methodist Church of SA (Methodist?)

12 Other Congregational churches

African Congregation Faith Church of the RSA

African Congregational Apostolic Church (Apostolic?) 
Name, name, name ... 'n bllk op die name van die Onafhanklike Swart kerke

14 Other Lutheran churches

African Lutheran Christian Church

American Lutheran Mission of South Africa

16 Other Baptist churches

Africa Baptist Church of SA

African Baptist Apostle Church of SA (Apostolic?)

African Emmanuel Baptist Church of SA

18 Other Catholic churches

Advent Catholic Church in RSA

African American Catholic Church of St. Monic in SA

African Bantu Catholic Church

23 Other Assemblies

African Emmanuel Assembly of God

African Latter Rain Assemblies of SA (Pentecostal?)

25 Other Pentecostal churches

Africa Back to God Ministry

Africa Gospel Crusade God

African Faith Gospel Healing Mission of SA

26 Christian Centres

African Christian Union Church of SA

28 Other Evangelical churches

Africa Christian Brethren Church

Africa Evangelical Fellowship Church

Africa Evangelistic Band

African Evangelical church

30 Other Charismatic churches

African Church of the Holy Spirit (Pentecostal?)

32 Other (Seventh Day) Adventist churches

Abalindi Seventh Day Church

African Church of Keeping in Sabbath in SA

34 Other Orthodox churches

African Orthodox Church

African Orthodox Church Province RSA 


\section{Other Apostolic Churches}

A G Jerusalem Apostolic Church

Abantu Apostolic Christ Church of SA

40 Other Zionist churches

A One Zion Elected Church of SA

Abaistraele (sic) Basikalele Apostohic Church in Zion

42 Ethnic churches

African Banda Church

African Bavenda Church

43 Other Ethiopian type churches

A.N.K. Apostolic Bantu Church of SA

Africa Holy National Church of Ethiopia

Hopelik sal hierdie klassifikasie van meer waarde wees as die vorige. Aanpassings mag in die toekoms nodig wees, maar behoort nie ingrypend te wees nie.

\section{Slot}

Die groep Onafhanklike Swart Kerke het mettertyd statisties en teologies een van die belangrikste verskynsels op die Suid-Afrikaanse godsdienstige toneel geword. Tog is daar in baie opsigte min oor hulle bekend. Hierdie artikel het aandag gegee aan een aspek van hierdie saak: die klassifikasie op grond van hulle name.

\section{Bronnelys}

KRITZINGER, J J. 1986a Die godsdiens-mosaiek van Suid-Afrika Pretoria : ISWEN

KRITZINGER, J J. 1986b. The religious mosaic of South Africa. Africa Insight, 16:93-108.

KRITZINGER, J.J. 1986c What the statistics tell us about the African Indigenous Churches in

South Africa. (In Oosthuizen, G.C., ed. Religion alive. Studies in the new movements and Indigenous Churches in Southern Africa. Johannesburg : Hodder \& Stoughton. p. 253-261.)

KRITZINGER, J.J. 1993a The numbers game: Independent Churches Africa Insight, 23:4, 246-249.

KRITZINGER, J J. 1993b The religious scene in present-day South Africa (In Kilian, J., ed. Religious freedom in South Africa. Pretoria : Unisa. p 1-13.)

KRITZINGER, J J. 1994 Christians in South Africa: The statistical picture. Hervormde Teologiese Studies, 50:3, 610-618

SUNDKLER, Bengt G M. 1961. Bantu prophets in South Africa London : OUP 
